\title{
KONSEP PEMBELAJARAN MULTIPLE INTELLIGENCES BAGI ANAK USIA DINI
}

\author{
Masdudi \\ Institut Agama Islam Negeri (IAIN) Syekh Nurjati Cirebon \\ Email:masdudi@gmail.com
}

Artukel Diterima: 22 Februari 2017 Proses Review Artikel: 24 Agustus 2017

Artikel Diterbitkan: 30 September 2017

\begin{abstract}
ABSTRAK
Pendidikan bagi anak usia dini memang pendidikan yang paling dasar bagi anak. Pada tahap ini orang tua harus benar-benar memperhatikan pendidikan bagi anaknya. Baik dalam memilih lembaga pendidikan bagi sang anak atau pun memilih untuk mendidik sendiri sang anak dirumah. Dalam pendidikan anak usia dini hendaknya memperhatikan kecerdasan yang dimiliki oleh anak. Karena kecerdasan anatara satu anak dengan yang lain berbeda. Orang tua maupun pendidik anak usia dini harus mengenali kecerdasan yang dimiliki anak agar dapat mengarahkan dan mengembangkan kecerdasan yang dimiliki anak secara maksimal. Teori multiple intelligences mempunyai pengaruh besar dalam proses pembelajaran di sekolah. Di Amerika Serikat, banyak sekolah seperti Proyek Zero dari Harvard University yang dipimpin Howard Gardner mulai mengembangkan pembelajaran yang menggunakan prinsip teori multiple intelligences. Dan hasil yang dicapai adalah banyak siswa yang tadinya diperkirakan tidak dapat berhasil dalam studi mereka tenyata dapat dibantu, dan berhasil dengan baik berkat pengajaran dengan multiple intelligences. Demikian juga banyak guru yang tadinya merasa tidak dapat membantu anak didik karena mengajar dengan model yang sama terus-menerus ternyata dapat membantu anak didik untuk berhasil karena mereka dapat mengembangkan pengajaran yang bervariasi.Menurut multiple intelligences, setiap siswa mempunyai intelegensi yang berbeda dan siswa akan lebih mudah belajar dan dibantu belajar bila materi diajarkan dengan intelegensi mereka yang menonjol. Oleh karena intelegensi siswa di satu kelas bervariasi, maka guru perlu memasukkan dan mengolah materi yang akan diajarkan dengan model multiple intelligences sesuai dengan intelegensi siswa-siswa tersebut. Guru perlu mengajar dengan model yang bervariasi sehingga setiap siswa merasa perlu dibantu secara tepat. Maka, sangat baik sebelum mengajar guru mencoba mengenali intelegesi apa saja yang dimiliki siswanya.
\end{abstract}

Kata Kunci: Multiple Intelligences dan Pendidikan

\section{PENDAHULUAN}

Kecerdasan adalah kemampuan memecahkan masalah dan menciptakan kreativitas. Kemampuan dari kata dasar mampuberasal dari dua hal, yaitu:(1) pembiasaan-pembiasaan yang disebabkan oleh perilaku fisik. Tindakan ini dihasilkan oleh gerakan kinetik tubuh, seperti memainkan alat musik, membentuk pola, menentukan gradasi warna, melakukan tendangan 
pisang, atau menghindari lawan saat menggiring bola. (2) pembiasaan-pembiasaan yang disebabkan oleh faktor nonfisik. Tindakan ini berupa pemikiran yang terpola dalam bentuk kebiasaan dalam kemampuan mengolah kata, memahami perhitungan bilangan dalam matematika, merasa nyaman dan bahagia dalam interaksi personal, serta merefleksikan lingkungan (Munif Chatib, 2012: 88).

Feldam mendefinisikan kecerdasan sebagai kemampuan memahami dunia, berfikir secara rasional, dan menggunakan sumber-sumber secara efektif pada saat dihadapkan dengan tantangan. Henmon mendefinisikan intelegensi sebagai daya atau kemampuan untuk memahami. Wechsler mendefinisikan intelegensi sebagai totalitas kemampuan seseorang untuk bertindak dengan tujuan tertentu, berfikir secara rasional, serta menghadapi lingkungan dengan efektif. Berbagai definisi diatas memandang bahwa intelegensi merupakan suatu kemampuan tunggal (Hamzah Uno, 2010: 59).

Menurut Gardner salah besar apabila mengasumsikan bahwa $I Q$ adalah suatu entitas atau besaran tunggal dan tetap, yang bisa diukur dengan tes menggunakan pensil dan kertas. Kecerdasan dalam definisi Gardner adalah sebuah kebudayaan yang tercipta dari proses pembelajaran, perilaku, pola kehidupan antar manusia, dan alam atau lingkungan yang terkristalisasi dalam habit (kebiasaan). Dengan demikian, kecerdasan adalah sebuah perilaku yang diulang-ulang (Munif Chatib, 2012: 79).

Kecerdasan adalah kemampuan untuk memproses jenis informasi tertentu yang berasal dari faktor biologis dan psikologis manusia. Suatu kecerdasan melibatkan kemampuan untuk memecahkan masalah atau merancang suatu produk yang merupakan konsekuensi dari komunitas atau latar budaya tertentu. Keahlian pemecahkan masalah memungkinkan seseorang untuk mendeskripsikan suatu situasi dimana sasarannya akan diperoleh dan menentukan rute memadai menuju sasaran. Penciptaan produk kultural memungkinkan seseorang untuk menangkap dan menyampaikan pengetahuan atau mengungkapkan kesimpulan, keyakinan, atau perasaan seseorang (Howard Gardner, 2013: 19).

Multiple Intelligences merupakan teori kecerdasan yang dikemukakan oleh Howard Gardner, seorang psikolog dari Harvard University, bahwa setiap anak punya kecenderungan kecerdasan dari sembilan kecerdasan, yaitu cerdas bahasa (linguistik), cerdas matematis-logis (kognitif), cerdas gambar dan ruang (visual-spasial), cerdas musik, cerdas gerak (kinestetis), cerdasmbergaul (interpersonal), cerdas diri (intrapersonal), cerdas alam, dan cerdas eksistensi (Munif Chatib, 2013: 87-88). 
Teori kecerdasan majemuk adalah validasi tertinggi gagasan bahwa perbedaan individu adalah penting. Pemakaiannya dalam pendidikan sangat tergantung pada pengenalan, pengakuan, dan penghargaan terhadap berbagai cara siswa belajar serta pengenalan, pengakuan dan penghargaan terhadap setiap minat dan bakat masing-masing siswa. Teori kecerdasan majemuk bukan hanya mengakui perbedaan individual untuk tujuan-tujuan praktis, seperti pengajaran dan penilaian, tetapi juga menganggap serta menerimanya sebagai sesuatu yang normal, wajar, bahkan menarik dan sangat berharga (Julia Jasmine, 2007: 11-12).

Teori kecerdasan majemuk menawarkan bebagai macam cara dalam mendidik dan mengembangkan kemampuan anak. Kesempatan untuk berkreasi dalam pengembangan kemampuan anak sangat terbuka. Tentu saja hal ini searah dengan kemampuan anak yang menonjol pada beberapa kecerdasan. Beberapa poin yang harus diingat mengenai kecerdasan adalah (1) Semua orang memiliki semua kecerdasan tanpa terbatas oleh usia, jenis kelamin, bangsa ataupun kebudayaan. Setiap manusia dikaruniai kecerdasan yang sama walaupun pada akhirnya berbeda dalam fokus pengembangannya. (2) Kelemahan anak dalam satu jenis kecerdasan bukanlah berarti dia kurang cerdas. Penemuan kecerdasan yang tepat dapat membuat ia mengembangkan kecerdasannya dengan baik. (3) Tidak ada kecerdasan yang lebih baik dari lainnya. Sehingga, anak yang cerdas dalam matematis-logis tidak lebih cerdas dari anak yang pandai menggambar. (4) Nilai suatu kecerdasan tidaklah statis. Seseorang yang unggul dalam satu kecerdasan dan lemah dalam kecerdasan lain dapat menutupi kelemahannya dengan pendalaman, perbaikan dan pengembangan. (5) Berbagai cara dapat dikembangkan untuk menjadi cerdas dalam setiap kecerdasan. Tak ada satupun cara yang efektif untuk semua kecerdasan. Oleh karenanya, setiap kecerdasan memerlukan pola pendidikan yang berbeda (Asep Dadang, 2007: 17-18).

Gardner tidak memandang kecerdasan manusia berdasarkan skor tes standar semata, namun Gardner menjelaskan kecerdasan sebagai kemampuan untuk menyelesaikan masalah yang terjadi dalam kehidupan manusia, kemampuan untuk menghasilkan persoalan-persoalan baru untuk diselesaikan dan kemampuan untuk menciptakan sesuatu atau menawarkan jasa yang akan menimbulkan penghargaan dalam budaya seseorang (Linda Campbell dkk, 1999: 2).

Ketika ditarik ke dunia pendidikan maka Multiple Intelligences menjadi sebuah strategi pembelajaran. Strategi Multiple Intelligences dapat digunakan untuk materi apapun dalam semua bidang studi. Strategi ini dapat menampung semua metodologi pembelajaran. Inti strategi Multiple Intelligences adalah cara guru mengemas gaya mengajarnya agar 
mudah ditangkap dan dimengerti oleh siswanya. Dengan kata lain guru perlu menyesuaikan gaya mengajarnya dengan gaya belajar siswa (Munif Chatib, 2011: 108).

Menurut teori intelegensi ganda seorang anak dapat mempelajari materi apapun, asalkan materi itu disampaikan sesuai dengan intelegensi yang cocok dengan intelegensi yang menonjol pada anak. Oleh karena intelegensi anakanak sekolah menengah beraneka ragam, guru perlu menggunakan cara mengajar yang beraneka ragam pula agar setiap anak merasa diperhatikan dan dibantu sesuai dengan intelegensi yang mereka punyai (Paul Suparno, 2013: 14).

Multiple Intelligences ketika diterapkan dalam pendidikan merupakan suatu teori yang memperlakukan semua peserta didik dengan perlakuan yang sama dan istimewa. Teori ini menganggap bahwa tidak ada anak yang bodoh atau pintar, yang ada yaitu anak yang menonjol dalam satu atau beberapa jenis kecerdasan. Sehingga Guru harus mampu merancang metode pembelajaran yanng dapat mengoptimalkan kecerdasan peserta didik.

Guru memiliki peran yang sangat penting dalam kegiatan pembelajaran di kelas. Tugas guru adalah merancang dan melaksanakan proses pembelajaran yang memungkinkan siswa dapat memperoleh pengalaman yang bermakna dan berguna bagi kehidupan mereka di masa yang akan datang. Pembelajaran yang dirancang dan dilaksanakan oleh guru hendaknya adalah pembelajaran yang efektif untuk mencapai tujuan yang ingin dicapai. Pembelajaran yang efektif tidak hanya terfokus pada hasil evaluasi yang dicapai oleh siswa, melainkan juga mampu memberikan pemahaman yang baik, ketekunan, kedisiplinan, semangat, dan rasa senang saat belajar.

Gagne, dalam Wina Sanjaya (2008: 213-215) mengungkapkan bahwa mengajar merupakan bagian dari pembelajaran, dimana guru lebih ditekankan kepada bagaimana merancang atau mengaransemen berbagai sumber dan fasilitas yang tersedia untuk digunakan atau dimanfaatkan siswa dalam mempelajari sesuatu. Pembelajaran perlu memberdayakan semua potensi peserta didik untuk menguasai kompetensi yang diharapkan. Pemberdayaan diarahkan untuk mendorong pencapaian kompetensi dan perilaku khusus supaya setiap individu mampu menjadi pembelajar sepanjang hayat dan mewujudkan masyarakat belajar.

Menurut Azis Wahab dalam Solihatin (2009: 1) iklim pembelajaran yang dikembangkan oleh guru mempunyai pengaruh yang sangat besar terhadap keberhasilan dan gairah belajar siswa. Kualitas dan keberhasilan pembelajaran sangat dipengaruhi oleh kemampuan guru dan ketepatan guru dalam memilih dan menggunakan metode pembelajaran. Dengan demikianpemilihan model dan metode pembelajaran yang sesuai dengan tujuan 
kurikulum dan potensi siswa merupakan kemampuan dan keterampilan dasar yang harus dimiliki oleh guru.

\section{KAJIAN TEORETIK}

\section{Teori Perkembangan Kognitif}

a) Teori Piaget

Jean Piaget terkenal dengan teori kognitifnya yang berpengaruh penting terhadap perkembangan konsep kecerdasan. Psikolog Swiss yang hidup tahun 1896-1980 ini pada awalnya lebih tertarik pada bidang biologi dan filsafat khususnya epistemologi. Perkembangan intelegensi anak menurut Piaget mengandung tiga aspek, yaitu structure, content, dan function. Jadi, intelegensi anak yang sedang mengalami perkembangan, struktur (structure) dan content intelegensinya berubah atau berkembang. Dimana fungsi dan adaptasi akan tersusun sedemikian rupa, sehingga melahirkan rangkaian perkembangan, dan masing-masing mempunyai stuktur psikologis khusus yang menentukan kecapkapan pikiran anak (Djaali, 2007: 68).

Faktor yang berpengaruh dalam perkembangan kognitif (Dahar, 2011: 141) yaitu:

1) Fisik, Interaksi antara individu dan dunia luar merupakan sumber pengetahuan baru, tetapi kontak dengan dunia fisik itu tidak cukup untuk mengembangkan pengetahuan kecuali jika intelegensi individu dapat memanfaatkan pengalaman tersebut.

2) Kematangan, Kematangan sistem syaraf menjadi penting karena memungkinkan anak memperoleh manfaat secara maksimum dari pengalaman fisik. Kematangan membuka kemungkinan untuk perkembangan sedangkan kalau kurang hal itu akan membatasi secara luas prestasisecara kognitif. Perkembangan berlangsung dengan kecepatan yang berlainan tergantung pada sifat kontak dengan lingkungan dan kegiatan belajar sendiri.

3) Pengaruh sosial, Lingkungan sosial termasuk peran bahasa dan pendidikan, pengalaman fisik dapat memacu atau menghambat perkembangan struktur kognitif

4) Proses pengaturan diri yang disebut ekuilibrasi, Proses pengaturan diri dan pengoreksi diri, mengatur interaksi spesifik dari individu dengan lingkungan maupun pengalaman fisik,pengalaman sosial dan perkembangan jasmani yang menyebabkanperkembangan kognitif berjalan secara terpadu dan tersusun baik.

Piaget (dalam Dahar, 2011: 136-139) membagi perkembangan kognitif anak ke dalam empat periode utama yang berkorelasi dengan dan semakin canggih seiring pertambahan usia: 
1) Periode sensorimotor (usia $0-2$ tahun)

Menurut Piaget, bayi lahir dengan sejumlah refleks bawaan selain juga dorongan untuk mengeksplorasi dunianya. Skema awalnya dibentuk melalui diferensiasi refleks bawaan tersebut. Periode sensorimotor adalah periode pertama dari empat periode.Perkembangan kognitif dati tahap sensorik-motorik pada anak-anak akan terlihat pada upayanya untuk melakukan gerakan tertentu di antara lingkungan sekitarnya. Pada mulanya gerakan seorang bayi dilakukan secara spontan. Dorongan untuk melakukan gerakan tertentu selalu datang dari factor internal dirinya sendiri. Penyesuaian dan pengaturan dari proses awal, hi ngga hasilnya berlanjut baik secara kuantitatif maupun kuallitatif, seiring dengan perubahan yang terjadi pada schemata atau pengertian. Proses pembentukan pengetahuan anak-anak dimulai dari proses yang paling primitive, yaitu mencoba mengulang-ulang bunyi yang didegarkannya (Djaali, 2007: 69).

2) Periode praoperasional (usia 2-7 tahun)

Tahapan ini merupakan tahapan kedua dari empat tahapan. Dengan mengamati urutan permainan, Piaget bisa menunjukkan bahwa setelah akhir usia dua tahun jenis yang secara kualitatif baru dari fungsi psikologis muncul. Pemikiran (Pra) Operasi dalam teori Piaget adalah prosedur melakukan tindakan secara mental terhadap objek-objek. Giri dari tahapan ini adalah operasi mental yang jarang dan secara logika tidak memadai. Dalam tahapan ini, anak belajar menggunakan dan merepresentasikan objek dengan gambaran dan kata-kata. Pemikirannya masih bersifat egosentris: anak kesulitan untuk melihat dari sudut pandang orang lain. Anak dapat mengklasifikasikan objek menggunakan satu ciri, seperti mengumpulkan semua benda merah walau bentuknya berbeda-beda atau mengumpulkan semua benda bulat walau warnanya berbedabeda.

3) Periode operasional konkret (usia 7-11 tahun)

Tahapan ini adalah tahapan ketiga dari empat tahapan. Muncul antara usia enam sampai duabelas tahun dan mempunyai ciri berupa penggunaan logika yang memadai.Selama tahap operasional konkret perhatian anak mengarah kepada operasi logis yang sangat cepat.

4) Periode operasional formal (usia 11 tahun sampai dewasa)

Tahap operasional formal adalah periode terakhir perkembangan kognitif dalam teori Piaget. Tahap ini mulai dialami anak dalam usia sebelas tahun (saat pubertas) dan terus berlanjut sampai dewasa. Karakteristik tahap ini adalah diperolehnya kemampuan untuk berpikir secara abstrak, menalar secara logis, dan menarik kesimpulan dari informasi yang 
tersedia. Dalam tahapan ini, seseorang dapat memahami hal-hal seperti cinta, bukti logis, dan nilai. Ia tidak melihat segala sesuatu hanya dalam bentuk hitam dan putih, namun ada gradasi abu-abu di antaranya.

\section{b) Teori Bruner}

Bruner yang memiliki nama lengkap Jerome S.Bruner seorang ahli psikologi (1915) dari Universitas Harvard, Amerika Serikat, telah mempelopori aliran psikologi kognitif yang memberi dorongan agar pendidikan memberikan perhatian pada pentingnya pengembangan berfikir. Bruner banyak memberikan pandangan mengenai perkembangan kognitif manusia, bagaimana manusia belajar, atau memperoleh pengetahuan dan mentransformasi pengetahuan. Dasar pemikiran teorinya memandang bahwa manusia sebagai pemproses, pemikir dan pencipta informasi. Bruner menyatakan belajar merupakan suatu proses aktif yang memungkinkan manusia untuk menemukan hal-hal baru diluar informasi yang diberikan kepada dirinya.Menurut Bruner, dalam proses belajar siswa menempuh tiga tahap, yaitu:

1) Tahap informasi (tahap penerimaan materi)Dalam tahap ini, seorang siswa yang sedang belajar memperoleh sejumlah keterangan mengenai materi yang sedang dipelajari.

2) Tahap transformasi (tahap pengubahan materi)Dalam tahap ini, informasi yang telah diperoleh itu dianalisis, diubah atau ditransformasikan menjadi bentuk yang abstrakatau konseptual.

3) Tahap evaluasi

Dalam tahap evaluasi, seorang siswa menilai sendiri sampai sejauh mana informasi yang telah ditransformasikan tadi dapat dimanfaatkan untuk memahami gej ala atau masalah yang dihadapi (Muhibbin Syah, 2000: 110).

\section{KonsepMultiple Intelligences}

Howard Gardner mendefinisikan intelegensi sebagai kemampuan untuk memecahkan persoalan dan menghasilkan produk dalam suatu seting yang bermacam-macam dan dalam situasi yang nyata (Paul Suparno, 2013:17). Gardner juga mendefinisikan kecerdasan sebagai potensi biopsikologi untuk memproses bentuk-bentuk informasi yang spesifik dalam cara-cara tertentu. Gardner memberikan definisi tentang kecerdasan sebagai kecakapan untuk memecahkan masalah yang dihadapi dalam kehidupannya, kecakapan untuk mengembangkan masalah baru untuk dipecahkan dan kecakapan untuk membuat sesuatu atau 
melakukan sesuatu yang bermanfaat di dalam kehidupannya (Nana Syaodih Sukmadinata, 2011: 96).

Sedangkan kata Multiple secara bahasa berarti perkalian atau kelipatan seperti dalam istilah lowest common multiple (kelipatan persekutuan kecil). Multiple juga berarti ganda seperti dalam istilah multiple choice (pilihan ganda). Kata multiple dalam pengertian multiple intelligences disini artinya ganda.

Menurut Gardner arti dari multiple intelligence adalah kemampuan untuk menyelesaikan masalah, untuk mendapatkan jawaban yang spesifik dan untuk belajar materi baru dengan cepat dan efisien (Howard Gardner, 2013: 14). Multiple Intelligences adalah sebuah penilaian yang melihat secara deskriptif bagaimana individu menggunakan kecerdasannya untuk memecahkan masalah dan menghasilkan sesuatu (Indra Soefandi, 2009: 56).

Berdasarkan definisi diatas, penulis dapat menyimpulkan bahwa multiple intelligences adalah teori kecerdasan yang ditemukan dan dikembangkan oleh Howard Gardner. Teori ini menjelaskan bahwa individu memiliki kecenderungan kecerdasan dari sembilan kecerdasan yaitu kecerdasan linguistik, kecerdasan matematis-logis, kecerdasan visualspasial, kecerdasan musik, kecerdasan kinestetik, kecerdasan intrepersonal, kecerdasan intrapersonal, kecerdasan naturalis dan kecerdasan eksistensial yang digunakan individu untuk memecahkan masalah dalam kehidupannya dan menciptakan sesuatu yang bermanfaat.

\section{Latar Belakang Munculnya Teori Multiple Intelligences}

Pada waktu membahas latar belakang pemikiran teori Multiple Intelligences Gardner menjelaskan empat hal, yaitu: gagasan mengenai Multiple Intelligences, pandangan awal tentang kecerdasan, fondasi biologis kecerdasan dan apa itu kecerdasan (Agus Efendi, 2005: 137). Di tahun 1979 sebuah tim kecil peneliti di Harvard Graduate School of Education diminta oleh Bernard Van Leer Foundation dari Den Haag untuk melakukan penelitian mengenai topik besar: Sifat Alami dan Realisasi Potensi Manusiall. Sebagai anggota yunior dari kelompok riset tersebut, dia mendapat tugas yang mengecilkan hatinya tetapi menghibur. Tugasnya, tak kurang dari menulis monograf mengenai apa yang telah diterima dalam ilmu pengetahuan manusia mengenai sifat alami manusia belajar. Ketika ia mulai penelitian yang mencapai puncaknya dalam penerbitan Frames of Mind di tahun 1983, dia memandang usaha ini sebagai peluang untuk melakukan sintesis usaha risetnya sendiri dengan anak-anak dan orang dewasa yang cedera otaknya. Sasarannya adalah menghasilkan pandangan mengenai pemikiran manusia 
yang lebih luas dan lebih lengkap dari pada yang telah diterima dalam penelitian belajar. Target yang ia incar adalah Konsep pengaruh dari Jean Piaget, yang memandang semua pemikiran manusia sebagai usaha keras ke arah pemikiran ideal; dan pencetusan buah pemikiran lazim mengenai inteligensi yang mengkaitkannya dengan kemampuan menyediakan jawaban singkat secara cepat pada masalah yang menyangkut keterampilan linguistik dan logika (Howard Gardner, 2011: 7-8).

Proyek zero adalah pusat penelitian dan pendidikan yang mengembangkan cara belajar, berfikir, dan kreativitas dalam mempelajari suatu bidang bagi individu dan institusi. Teori intelegensi ganda banyak mendasari Proyek Zero (Paul Suparno, 2013: 17). Dalam usaha ini, ilmu pengetahuan mencoba menemukan uraian yang tepat mengenai inteligensi. Untuk mencoba menjawab pertanyaan ini, Howard Gardner bersama rekanrekannya mengadakan penelitian yang belum pernah dipertimbangkan secara bersamaan sebelumnya. Yakni, sebuah sumber mengenai apa yang sudah kita ketahui menyangkut pengembangan jenis ketrampilan yang berbeda dalam diri anak-anak normal dan informasi mengenai cara kemampuan ini hilang atau menyusut karena adanya kerusakan otak. Riset yang menyangkut pasien dengan kerusakan otak ini menghasilkan semacam bukti yang amat kuat, karena mencerminkan cara sistem syaraf mengalami evolusi selama beberapa milenium untuk menghasilkan jenis inteligensi yang berdiri sendiri. Kelompok risetnya juga mengamati populasi khusus antara lain: orang-orang yang luar biasa, orang yang amat cerdas dalam bidang tertentu tetapi nyaris tidak memahami bidang yang lain (idiot savant), anak-anak penderita autisme, anak-anak yang tidak mampu belajar, semua yang menunjukkan profil pemahaman dengan perbedaan amat tajam; profil yang amat sulit dijelaskan dalam arti pandangan inteligensi yang menggunakan unit. Mereka juga meneliti pemahaman pada berbagai jenis binatang dan dalam budaya yang amat berbeda. Akhirnya, mereka mempertimbangkan dua jenis bukti psikologi: hubungan di antara tes psikologi dari jenis yang dihasilkan oleh analisis statistik secara seksama dari sederetan tes sejenis, dan hasil dari usaha pelatihan keterampilan (Howard Gardner, 2011: 23).

Ketika menjelaskan gagasan Multiple Intelligences, Gardner membuat ilustrasi seperti: Seorang perempuan muda bersama seorang penguji selama satu jam. Kepadanya diajukan sejumlah pertanyaan yang menyelidiki informasi yang dipahaminya dalam bidang sejarah: (Siapa yang menemukan Amerika? Apa yang dikerjakan oleh perut?), kemampuan aritmatikanya (jika satu batang permen seharga delapan sen, berapa harga tiga batang permen?), kemampuannya untuk mengingat rangkaiannomor $(5,1,7,4,2,3,8)$, 
kemampuannya untuk memahami kesamaan antara dua elemen (siku dan lutut, gunung dan danau). Dia juga diminta untuk mengerjakan tugas-tugas yang lain seperti memecahkan sebuah jaringan jalan yang ruwet atau menyusun sekelompok gambar-gambar sedemikian rupa sehingga gambar-gambar tersebut menjadi sebuah cerita yang sempurna. Setelah itu, penguji memberikan skor terhadap jawaban-jawaban tadi dan sampai pada satu angka kecerdasan intelegensi atau IQ perempuan tersebut (Howard Gardner, 2011:3).

Penilaian tersebut bukan saja mempengaruhi apresiasi masa depan perempuan itu, tetapi juga akan mempengaruhi penilaiannya gurunya. Kejadian seperti itu, menurut Gardner terjadi ribuan kali setiap hari di seluruh dunia. Tes-tes IQ tidak akan memadai untuk menaksir potensi atau prestasi seseorang. Masalahnya terletak pada teknologi pengujiannya. Hanya jika kita memperluas dan mereformulasi pandangan mengenai apa itu kecerdasan manusia maka akan mampu memiliki cara yang lebih tepat untuk menaksir kecerdasan itu dan cara yang lebih efektif untuk mendidiknya (Agus Efendi, 2005: 137).

Oleh sebab itu, Gardner mengajukan teori Multiple Intelligences yang ditegaskannya sebagai a new theory of human intellectual competence. Inilah teori yang menantang pandangan klasik tentang kecerdasan yang secara eksplisit atau implisit telah menyihir melalui psikologi dan teks-teks pendidikan sejak 2.000 tahun lalu (Agus Efendi, 2005: 138).

Menurut Gardner, lebih dari dua ribu tahun, minimal sejak bangkitnya negara-negara Yunani, terdapat serangkaian ide mendominasi diskusidiskusi mengenai kondisi manusia dalam suatu peradaban. Ide-ide ini menekankan pada eksistensi dan pentingnya kekuatan mental, yaitu kemampuan manusia yang kemudian diungkapkan dengan berbagai tema, seperti rasionalitas, intelegensi, atau penyebaran pikiran. Dalam pencarianya mengenai esensi manusia, Gardner melakukan penelitian terhadap kemampuan-kemampuan khusus dari beberapa tokoh, seperti Plato, ahli-ahli kitab terpelajar di biara, atau ilmuwan di laboratorium (Howard Gardner, 2011: 5).

Dari perspektif sejarah peradaban Barat, terutama pada abad kegelapan, yang mengantarai abad klasik dan renaissance, persoalan kecerdasan ini jarang ditentang. Pada awal abad pertengahan St. Agustine menegaskan bahwa pengarang dan penggerak utama alam semesta itu adalah kecerdasan. Oleh karena itu, sebab akhir alam semesta itu haruslah baiknya kecerdasan. Seluruh manusia itu mencari kearifan, dan pencarian kearifan adalah sesuatu yang paling sempurna, paling luhur, paling berguna dan paling dapat disepakati (Agus Efendi, 2005: 138). 
Dalam kesimpulan Gardner, ada bukti persuasif mengenai adanya beberapa kompetensi intektual manusia yang otonom secara relatif, yang disebut dengan kecerdasan manusiall. Inilah yang disebut oleh Gardner dengan frames of mindll. Jumlah persis kecerdasan itu belum ditetapkan namun diyakini bahwa minimal ada beberapa jenis kecerdasan yang relatif tidak bergantung satu sama lain.

\section{Pendidikan Anak Usia Dini Berbasis Multiple Intelligences}

Pendidikan bagi anak usia dini memang pendidikan yang paling dasar bagi anak. Pada tahap ini orang tua harus benar-benar memperhatikan pendidikan bagi anaknya. Baik dalam memilih lembaga pendidikan bagi sang anak atau pun memilih untuk mendidik sendiri sang anak dirumah. Dalam pendidikan anak usia dini hendaknya memperhatikan kecerdasan yang dimiliki oleh anak. Karena kecerdasan anatara satu anak dengan yang lain berbeda. Orang tua maupun pendidik anak usia dini harus mengenali kecerdasan yang dimiliki anak agar dapat mengarahkan dan mengembangkan kecerdasan yang dimiliki anak secara maksimal.

Menurut Howard Gardner seorang pencetus teori Multiple intelligences, terdapat sembilan jenis kecerdasan manusia yaitu:

1) Kecerdasan matematika dan logika. Kecerdasan logis matematis memuat kemampuan seseorang dalam berfikir secara induktif dan deduktif, berfikir menurut aturan logika, memahami dan menganalisis pola angka-angka, serta memecahkan masalah dengan menggunakan kemampuan berfikir. Kemampuan ini bisa diasah lewat permainan yang menggunakan angka-angka, misalnya bermain. Untuk merangsang serta mengoptimalkan kecerdasan logis-matematis, anda harus mengondisikan otak anak agar siap menerima materi dengan situasi dan cara pembelajaran yang menyenangkan.

2) Kecerdasan bahasa. Kecerdasan bahasa memuat kemampuan seseorang untuk menggunakan bahasa dan kata-kata, baik secara tertulis maupun lisan, dalam berbagai bentuk yang berbeda untuk mengekspresikan gagasan-gagasannya. Kecerdasan bahasa biasanya tampak dalam beberapa aspek, seperti retorika, yaitu kemampuan menggunakan bahasa untuk meyakinkan orang lain; mnemonik, yaitu kemampuan untuk membantu orang lain mengingat berbagai macam informasi; penjelasan, yaitu kemampuan untuk menjelaskan; dan metalinguistik, yaitu kemampuan menggunakan bahasa untuk membuat refleksi atas bahasa itu sendiri. Ada beberapa cara untuk meningkatkan kemampuan berbahasa pada anak. Selain mengajak bicara, 
membaca cerita, dan menyanyi, anda dapat juga memasukkannya kedalam aktivitas drama yang kerap digelar oleh sanggar kesenian anak

3) Kecerdasan visual spasial. Kecerdasan visual-spasial memuat kemampuan seseorang untuk memahami secara lebih mendalam dalam hubungan antara objek dan ruang. Peserta didik ini memiliki kemampuan, misalnya untuk menciptakan imajinasi bentuk dalam pikirannya atau kemampuan untuk menciptakan bentuk-bentuk tiga dimensi seperti dijumpai pada orang dewasa yang menjadi pemahat patung atau arsitektur suatu bangunan. Kemampuan membayangkan suatu bentuk nyata dan kemudian memecahkan berbagai masalah sehubungan dengan kemampuan ini adalah hal yang menonjol pada jenis kecerdasan visual-spasial. Peserta didik yang demikian akan unggul, misalnya dalam permainan mencari jejak pada suatu kegiatan kepramukaan. Kemampuan meningkatkan kecerdasan spasial bisa dilakukan sedini mungkin dengan belajar mengamati benda-benda dalam berbagai bentuk, menemukan cara-cara untuk keluar dari suatu ruangan hanya dengan membayangkannya, menggambarkan apa yang dibayangkan, menikmati gambar-gambar abstrak, belajar dengan menggunakan diagram, menyusun atau menggabungkan bentuk-bentuk bangun tertentu dan menghasilkan bentuk bangun yang baru.

4) Kecerdasan musical. Kecerdasan musikal memuat kemampuan seseorang peka terhadap suara-suara nonverbal yang berada di sekelilingnya, termasuk dalam hal ini adalah nada dan irama. Peserta didik jenis ini cenderung senang sekali mendengarkan nada dan irama yang indah, entah melalui senandung yang dilagukan sendiri, mendengarkan tape recorder, radio, pertunjukan orkestra, atau alat musik yang dimainkannya sendiri. Mereka juga lebih mudah mengingat sesuatu dengan mengekspresikan gagasan-gagasan apabila dikaitkan dengan musik. Kecerdasan musik pada anak pun dapat dirangsang sejak dini. Anak-anak diajarkan melalui irama dan melodi. Semua bisa dipelajari dengan mudah, bila hal itu dinyanyikan atau diberi aba-aba dengan ketukan menurut irama. Anak diperkenalkan dengan lagu-lagu dan ritme. Pengenalan lagu-lagu harus dilakukan secara bertahap dan sesuai usia.

5) Kecerdasan kinestetik. Kecerdasan kinestetik memuat kemampuan sesorang untuk secara aktif menggunakan bagian-bagian atau seluruh tubuhnya untuk berkomunikasi dan memecahan berbagai masalah. Hal ini dapat dijumpai pada pesrta didik yang unggul pada salah satu cabang olahraga, seperti bulu tangkis, sepak bola, tenis, renang, dan sebagainya, atau bisa pula tampil pada peserta didik yang pandai menari, terampil bermain akrobat, atau unggul dalam bermain sulap. Pengoptimalan kecerdasan kinestetik dapat dilakukan dengan 
berbagai permaianan yang berorientasi pada kegiatan bergerak secara fisik. Contoh permainan ini yaitu,n menari, bermain peran, melompat, menari, main dorong-dorongan, permainan bola dll.

6) Kecerdasan interpersonal. Kecerdasan intrapersonal menunjukkan kemampuan seseorang untuk peka terhadap perasaan orang lain. Mereka cenderung untuk memahami dan berinteraksi dengan orang lain sehingga mudah bersosialisasi dengan lingkungan di sekelilingnya. Kecerdasan semacam ini juga sering disebut sebagai kecerdasan sosial, yang selain kemampuan menjalin persahabatan yang akrab dengan teman, juga mencangkup kemampuan seperti memimpin, mengorganisasi, menangani perselisihan antar teman, memperoleh simpati dari peserta didik yang lain, dan sebagainya. Untuk mengoptimalkan kecerdasan ini anda dapat memberikan permainan-permainan yang bisa memunculkan berbagai perasaan. Misalnya menunjukkan perasaan sedih, gembira, kesal, kecewa, bahagia dan lain-lain. Sebelumnya anda harus menunjukkan dulu berbagai perasan emosi tersebut, jelaskanlah situasi-situasi yang menimbulkannya, lalu anak akan memainkan peran sedang sedih, kesal, dan lain-lain.

7) Kecerdasan intrapersonal. Kecerdasan interpersonal menunjukkan kemampuan seseorang untuk peka terhadap perasaan dirinya sendiri. Ia cenderung mampu untuk mengenali berbagai kekuatan maupun kelemahan yang ada pada dirinya sendri. Peserta didik semacam ini senang melakukan intropeksi diri, mengoreksi kekurangan maupun kelemahannya, kemudian mencoba untuk memperbaiki diri. Beberapa diantaranya cenderung menyukai kesunyian dan kesendirian, merenung, dan berdialog dengan dirinya sendiri. Permainan yang dapat merangsang perkembangan kecerdasan interpersonal yaitu, misalnya bermain pura-pura, bermain telepon, dll. dorong anak untuk melakukan aktifitas belajar kelompok.

8) Kecerdasan naturalis. Kecerdasan naturalis ialah kemampuan seseorang untuk peka terhadap lingkungan alam, misalnya senang berada dilingkungan alam yang terbuka, seperti pantai, gunung, cagar alam, atau hutan. Peserta didik dengan kecerdasan seperti ini cenderung suka mengobservasi lingkungan alam seperti aneka macam bebatuan, jenis-jenis lapisan tanah, aneka macam flora dan fauna, benda-benda angkasa, dan sebagainya. Belajar dengan cara naturalis dapat dilakukan di perumahan yang aman, nyaman, asri, dekat dengan danau, dan bebas polusi, karena tidak dilewati kendaraan umum.

9) Kecerdasan eksistensial. Kecerdasan eksistensial sering dinilai sebagai bagian dari kecerdasan spiritual atau Spiritual Quetient (SQ). Kecerdasan ini kiranya harus dipandang sebagai sifat 
yang harus dikembangkan pada diri setiap anak, apa pun bakat dan kemampuannya demi memastikan bahwa pada pucaknya sang anak dapat menjadikan bakat serta kemampuannya itu untuk memperoleh kesuksesan dan kebahagiaan hidup. (Widayati, Sri dan Widjiati, Utami. 2008.)

\section{Faktor-faktor yang Mempengaruhi Multiple Intelligences}

Kecerdasan yang dimiliki seseorang dapat berkembang sampai tingkat kemampuan yang disebut mumpuni. Pada tingkat ini, kemampuan seseorang di bidang tertentu, yang berkaitan dengan kecerdasan itu, akan terlihat sangat menonjol. Menurut Armstrong (1993:21-22) berkembang tidaknya suatu kecerdasan bergantung pada tiga faktor penting berikut:

a. Faktor biologis (biological endowment), termasuk di dalamnya faktor keturunan atau genetis dan luka atau cedera otak sebelum, selama, dan setelah kelahiran.

b. Sejarah hidup pribadi, termasuk di dalamnya adalah pengalamanpengalaman (bersosialisasi dan hidup) dengan orang tua, guru, teman sebaya, atau orang lain, baik yang membangkitkan maupun yang menghambat perkembangan kecerdasan.

c. Latar belakang kultural dan historis, termasuk waktu dan tempatseseorang dilahirkan dan dibesarkan serta sifat dan kondisiperkembangan historis atau kultural di tempat yang berbeda.

Sedangkan menurut menurut Djaali (2007: 74-75) faktor-faktor yang dapat mempengaruhi intelegensi sehingga terdapat perbedaan intelegensi seseorang dengan yang lain, diantaranya:

1. Faktor pembawaan. Faktor ini ditentukan oleh sifat yang dibawa sejak lahir. Batas kesanggupan atau kecakapan seseorang dalam memecahkan masalah, antara lain ditentukan oleh faktor bawaan. Oleh karena itu, di dalam satu kelas dapat dijumpai anak yang cepat dan lambat dalam menerima informasi meskipun mereka menerima pelajaran dan pelatihan yang sama.

2. Faktor minat dan pembawaan khas. Minat mengarahkan perbuatan kepada suatu tujuan dan merupakan dorongan bagi perbuatan itu. Dalam diri manusia terdapat dorongan atau motif yang mendorong manusia untuk berinteraksi dengan dunia luar, sehingga apa yang diminati oleh manusia dapat memberikan dorongan untuk berbuat lebih giat dan lebih baik.

3. Faktor pembentukan. Pembentukan adalah segala keadaan di luar diri seseorang yang mempengaruhi perkembangan intelegensi. Disini dapat dibedakan antara pembentukan 
sengaja, seperti yang dilakukan di sekolah dan pembentukan yang tidak disengaja, misalnya pengaruh alam di sekitarnya.

4. Faktor kematangan. Tiap organ dalam tubuh manusia mengalami pertumbuhan dan perkembangan. Setiap organ manusia baik fisik maupun psikis, dapat dikatakan telah matang, jika ia telah tumbuh atau berkembang hingga mencapai kesanggupan menjalankan fungsinya masing-masing. Oleh karena itu, tidak mengherankan bila anak-anak belum mampumengerjakan atau memecahkan soal-soal matematika di kelas empat sekolah dasar, karena soal-soal itu masih terlampau sukar bagi anak. Organ tubuhnya dan fungsi jiwanya masih belum matang untuk menyelesaikan soal tersebut dan kematangan berhubungan erat dengan umur.

5. Faktor kebebasan. Yang berarti manusia dapat memilih metode tertentu dalam memecahkan masalah yang dihadapi. Disamping kebebasan memilih masalah yang sesuai dengan kebutuhannya.

Bayley (1979) didalam studinya menemukan beberapa faktor yang mempengaruhi kemampuan intelektual individu, yaitu:

a) Keturunan. Studi korelasi nilai-nilai tes intelegensi diantara anak dan orang tua, atau dengan kakek-neneknya, menunjukkan adanya pengaruh faktor keturunan terhadap tingkat kemampuan mental seseorang pada tingkat tertentu.

b) Latar belakang sosial ekonomi. Pendapatan keluarga, pekerjaan orang tua dan faktorfaktor sosial ekonomi lainnya, berkorelasi positif dan cukup tinggi dengan taraf kecerdasan individu mulai usia tiga tahun sampai dengan remaja.

c) Lingkungan hidup. Lingkungan yang kurang baik akan menghasilkan kemampuan intelektual yang kurang baik pula. Lingkungan yang dinilai paling buruk bagi perkembangan intelegensi adalah panti-panti asuhan serta institusi lainnya, terutama bila anak ditempatkan disana sejak awal kehidupannya.

d) Kondisi fisik. Keadaan gizi yang kurang baik, kesehatan yang buruk, perkembangan fisik yang lambat, menyebabkan tingkat kemampuan mental yang rendah. Perkembangan anak sangat dipengaruhi oleh gizi yang dikonsumsi. Oleh karena itu ada hubungan antara pemberian makanan bergizi dengan inteligensi seseorang. Pemberian makanan bergizi inimerupakan salah satu pengaruh lingkungan yang amat penting selain guru, rangsanganrangsangan yang bersifat kognitif emosional dari lingkungan juga memegang peranan 
yang amat penting, seperti pendidikan, latihan berbagai keterampilan, dan lain-lain. Periode emas proses perkembangan otak anak terdiri dari serangkaian tahapan yang telah dimulai sejak di dalam kandungan. Tepatnya, ketika kehamilan memasuki trimester ke-3. Tahapan itu berlanjut setelah anak lahir dan perkembangan yang berlangsung hingga usia 2 tahun merupakan periode emas atau periode pacu tumbuh otak. Pada usia 6 bulan, perkembangan otak anak mencapai $50 \%$, pada umur 2 tahun melonjak hingga $75 \%$, pada umur 5 tahun perkembangan otak mencapai $90 \%$ dan pada umur 10 tahun mencapai $99 \%$. Kecerdasan sangat ditentukan oleh bagaimana perkembangan dan pertumbuhan otak saat dalam kandungan dan setelah kelahiran. Gizi yang cukup dan memenuhi kebutuhan merupakan penentu utama dalam pertumbuhan dan perkembangan otak dari sejak dalam kandungan sampai fase tersebut selesai. Kekurangan gizi akan menyebabkan beberapa efek serius seperti kegagalan pertumbuhan fisik, menurunnya perkembangan kecerdasan, kekurangan gairah belajar, menurunnya produktivitas dan kreativitas, serta meningkatnya risiko penyakit karena daya tubuh menurun.

e) Iklim emosi. Iklim emosi dimana individu dibesarkan mempengaruhi perkembangan mental individu yang bersangkutan. (Slameto, 2010: 131).

Berdasarkan pemaparan diatas, penulis dapat menyimpulkan bahwa kecerdasan dipengaruhi dua faktor utama yang saling terkait yaitu faktor keturunan (bawaan, genetik) dan faktor lingkungan. Seorang anak dapat mengembangkan berbagai kecerdasan jika mempunyai faktor keturunan dan dirangsang oleh lingkungan terus menerus.

\section{Kriteria Multiple Intelligences}

Gardner menjelaskan bahwa kemampuan-kemampuan manusia yang dimasukkan dalam multiple intelligences haruslah memenuhi delapan kriteria, yaitu:

a) Terisolasi dalam bagian otak tertentu

Kemampuan itu sungguh otonom, lepas dari kemampuan yang lain, terisolasi dari yang lain. Bila kemampuan ini hilang karena kerusakan otak, tidak akan mempengaruhi kerusakan kemampuan lainnya. Kesembilan intelegensi ini masing-masing berkaitan dengan bagian otak tertentu. Bila bagian otak itu rusak, maka hanya intelegensi itu yang hilang sedangkan yang lain tidak (Paul Suparno, 2013: 23). Setiap area otak yang disebut lobus of brain ternyata punya komponen inti berupa potensi kepekaan yang akan muncul dari setiap area otak apabila diberi stimulus yang tepat. Akibat adanya stimulus yang tepat, kepekaan inilah yang 
akan menghasilkan kompetensi. Howard Gardner memaparkan tiga hal yang berkaitan dengan multiple intelligences seseorang, yaitu komponen inti, kompetensi dan kondisi akhir terbaik

b) Kemampuan itu independen

Ini tampak pada kasus banyak orang yang pandai tapi idiot (idiot savants i) dan orang autis. Pada orang seperti itu, yang bersangkutan mempunyai kemampuan sangat tinggi dalam hal tertentu tetapi lemah pada kemampuan lainnya. Misalnya ada anak yang tidak dapat berfikir, tidak dapat berbicara, tetapi sangat tinggi kemampuan musiknya. Dari sini dapat dilihat bahwa kemampuan itu dalam seseorang saling independen, tidak terkait secara ketat, sehingga dapat dianggap sebagai intelegensi yang berdiri sendiri.

c) Memuat satuan operasi khusus

Intelegensi ini mengandung unsur satuan operasi khusus untuk bereaksi terhadap input yang datang. Setiap intelegensi mengandung keterampilan operasi tertentu yang berbeda satu sama lain dan dengan keterampilan operasi itu seseorang dapat mengekspresikan kemampuannya dalam menghadapi persoalan. Misalnya, intelegensi kinestetik-badani mempunyai kecepatan menirukan gerak orang lain, intelegensi musik punya kepekaan terhadap intonasi dan ritme sehingga orang dapat menangkap musik dengan cepat dan baik.

d) Mempunyai sejarah perkembangan sendiri

Setiap intelegensi mempunyai sejarah perkembangan sendiri, mempunyai waktunya sendiri dalam berkembang, menuju puncak lalu akan turun. Bila kita ingin melihat inti intelegensi secara jelas, perlu dilihat puncak intelegensi itu pada orang-orang yang berintelegensi tertentu secara luar biasa. Misalnya, dapat dilihat intelegensi musik pada Mozart, intelegensi kinestetikbadani pada Mohamad Ali pada saat jaya-jayanya menjadi jago tinju profesional, dan intelegensi linguistik pada WS. Rendra pada saat jayanya sebagai penyair dan dramawan.

e) Berkaitan dengan sejarah evolusi manusia zaman dulu

Setiap intelegensi dapat dilihat sejarah evolusinya pada kejadian dulu. Setiap intelegensi yang sekarang ini dapat dicari awalnya dari evolusi (perkembangan) manusia kuno, bahkan dari evolusi spesies lain, bukanhanya terjadi sekarang ini. Ini sejalan dengan perkembangan otak manusia dari manusia purba dan bahkan dari makhluk yang berkaitan. Misalnya, intelegensi musik dapat dirunut kembali melalui bukti arkeologis alat-alat musik kuno, intelegensi matematis-logis dapat dirunut lewat sistem bilangan zaman kuno dan sistem kalender yang ditemukan. 
f) Dukungan psikologi eksperimental

Dari tugas-tugas psikologis yang diberikan tampak bahwa intelegensi bekerja saling terisolasi. Misalnya, yang kuat dalam membaca belum tentu kuat dalam matematika. Demikian juga orang mempunyai kemampuan yang berbeda dan tertentu. Misalnya, ada orang yang sangat mudah mengenal kata-kata, tetapi sulit mengenal wajah orang; mudah mengenal suara, tetapi sulit mengenal musik, dan sebagainya. Dari sini jelas bahwa transfer dari intelegensi satu ke intelegensi lain sering tidak bisa.

g) Dukungan dari penemuan psikometrik

Dari beberapa tes psikologi terstandar dapat diyakini bahwa intelegensi yang ditemukan Gardner memang benar. Misalnya, Wechsler Intelligences Scale for Children yang mengandung tes intelegensi inguistik, matematis-logis, visual, dan kinestetikbadani.

h) Dapat disimbolkan

Salah satu tanda tingkah laku intelegensi manusia adalah kemampuannya untuk menggunakan simbol dalam hidup. Menurut Gardner, kesembilan intelegensi yang diteliti dapat disimbolkan dalam sistem notasi yang berbeda dan khas. Setiap intelegensi mempunyai simbol khusus dan sistem notasi khas. Misalnya, intelegensi linguistik dengan bahasa fonetik, intelegensi matematis-logis dengan bahasa komputer, intelegensi visual dengan bahasa ideografik, intelegensi kinestetik-badani dengan bahasa tanda, intelegensi musikal dengan sistem notasi musik, intelegensi interpersonal dengan bahasa wajah dan isyarat, intelegensi intrapersonal dengan bahasa simbol diri (Paul Suparno, $2013: 23-25$ ).

\section{Implikasi Multiple Intelligences Dalam Pendidikan}

Pendidikan adalah hal yang sangat penting untuk diperoleh anak-anak ataupun orang dewasa. Pendidikan menjadi salah satu modal bagi seseorang agar dapat berhasil dan mampu meraih kesuksesan dalam kehidupannya. Mengingat akan pentingnya pendidikan, maka pemerintah pun mencanangkan program wajib belajar sembilan tahun, melakukan perubahan kurikulum untuk mencoba mengakomodasi kebutuhan siswa. Dalam rumusan UU Sisdiknas tahun 2003 ditegaskan bahwa pendidikan adalah usaha sadar dan terencana untuk mewuj udkan suasana belaj ar dan proses pembelajaran agar peserta didik secara aktif 
mengembangkan potensi dirinya untuk memiliki kekuatan spiritual keagamaan, pengendalian diri, kepribadian, kecerdasan, akhlak mulia, serta keterampilan yang diperlukan dirinya, masyarakat, bangsa dan negara.

Multiple Intelligences yang dalam bahasa Indonesia diterjemahkan sebagai kecerdasan majemuk atau kecerdasan ganda merupakan salah satu teori kecerdasan yang memperoleh banyak pengakuan akhir-akhir ini. Teori ini dicetuskan oleh Howard Gardner, psikolog dari Harvard. Mula-mula Gardner menemukan tujuh jenis kecerdasan tetapi kemudian mengembangkan- nya menjadi sembilan kecerdasan.

Dalam dunia pendidikan, teori multiple intelligences mulai diterima karena dianggap lebih melayani semua kecerdasan yang dimiliki anak. Konsep Multiple Intelligences menjadikan pendidik lebih arif melihat perbedaan, dan menjadikan anak merasa lebih diterima dan dilayani. Konsep ini menghapus mitos anak cerdas dan tidak cerdas, karena menurut konsep ini, semua anak hakikatnya cerdas. Hanya saja konsep cerdas itu perlu diredefinisi dengan landasan baru. Dengan berkembangnya konsep multiple intelligences dan dengan diterimanya teori tersebut dalam dunia pendidikan, maka mau tidak mau pendidik perlu membantu tumbuh kembang anak dalam berbagai rencana, pelaksanaan, dan evaluasi program yang memberi wadah bagi perkembangan semua jenis kecerdasan mereka. Tugas ini menjadi sedemikian penting mengingat perkembangan danperwujudan semua jenis kecerdasan tersebut esensial bagi anak dalam mengatasi permasalahan-permasalahan dalam kehidupan, dan memperoleh kehidupan itu sendiri.

Dalam konsep Multiple Intelligences, perbedaan individual peserta didik diterima dan dilayani dengan suatu keyakinan berpijak sebagaimana dinyatakan Howard Gardner bahwa . kita semua begitu berbeda karena pada hakikatnya kita memiliki kombinasi inteligensi yang berbeda. Jika kita sadari hal ini, setidaknya kita lebih berpeluang untuk mampu mengatasi secara tepat berbagai problem yang kita hadapi dalam hidup di dunia”.'Aplikasi Multiple Intelligences dalam pendidikan akan menyebabkan pendidik lebih arif dan mampu menghargai serta memfasilitasi perkembangan anak.

1) Implikasi pada kurikulum

Dalam pengertian modern, kurikulum lebih dimengerti sebagai semua pengalaman yang direncanakan untuk dialami siswa dalam proses pendidikan sejak awal. Maka, bentuknya dapat berupa pengalaman dalam kelas, di luar kelas, atau di luar sekolah. Teori multiple 
intelligences banyak mempengaruhi penyusunan kurikulum, terutama di Amerika Serikat. Pengaruh yang menonjol adalah pemilihan materipelajaran melalui topik-topik tematik, bukan urutan bab seperti model kurikulum klasik. Banyak sekolah mulai pada awal pelajaran menentukan topik-topik yang akan dipelajari siswa. Topik biasanya ditentukan pemerintah lokal dan pilihan siswa. Ini untuk menjembatani ketentuan pemerintah lokal dan minat serta kesenangan siswa. Dengan demikian, diharapkan siswa selama satu semester sungguh senang belajar karena ikut andil dalam penentuan topik pelajaran. Model topik ini juga memungkinkan pendekatan secara indisipliner dilihat dari berbagai sudut. Misalnya topik energi: dapat didekati lewat pendekatan fisis, kimia, biologis, ekonomis, matematis, dan lingkungan. Dengan pendekatan tersebut, jelas multiple intelligences diperlukan dalam pendekatannya, bukan hanya pendekatan matematis dan lingusitik.

Teori multiple intelligences juga mempengaruhi bagaimana materi disajikan dan dipelajari. Pembelajaran berbeda dengan model klasik yang hanya ceramah dan hitungan, tetapi lebih dengan intelegensi yang bervariasi, sehingga lebih menyenangkan bagi siswa yang sedang belajar. Pendekatan ini juga menekankan pendekatan yang lebih personal dalam pendidikan karena situasi dan kekhasan siswa diperhatikan. Karena proses pembelajaran bervariasi, maka evaluasipun berubah. Pengaturan waktu, pengaturan kelas, bahkan pengaturan sekolah banyak pula mengalami perubahan. Penyusunan buku teks pun bervariasi dengan memasukan gambar, hitungan, musik, tugas kerja sama, refleksi pribadi dan penggunaan peralatan elektronik untuk membantu proses pembelajaran yang menggunakan multiple intelligences (Paul Suparno, 2013: 51-53).

Namun, ada beberapa sekolah tetap menggunakan susunan kurikulum klasik, tetapi dilengkapi dengan program dan kegiatan tambahan yang mengembangkan multiple intelligences. Ini agar tidak terlalu mengubah kurikulum yang ada secara drastis, yang sudah berjalan lama, tetapi ada pembaruan dan dilengkapi denagn unsur multiple intelligences.

2) Implikasi pada pembelajaran

Teori multiple intelligences mempunyai pengaruh besar dalam proses pembelajaran di sekolah. Di Amerika Serikat, banyak sekolah seperti Proyek Zero dari Harvard University yang dipimpin Howard Gardner mulai mengembangkan pembelajaran yang menggunakan prinsip teori multiple intelligences. Dan hasil yang dicapai adalah banyaksiswa yang tadinya diperkirakan tidak dapat berhasil dalam studi mereka tenyata dapat dibantu, dan berhasil 
dengan baik berkat pengajaran dengan multiple intelligences. Demikian juga banyak guru yang tadinya merasa tidak dapat membantu anak didik karena mengajar dengan model yang sama terus-menerus ternyata dapat membantu anak didik untuk berhasil karena mereka dapat mengembangkan pengajaran yang bervariasi.

Dalam penelitiannya, Gardner menemukan banyak guru yang mengajar dengan satu model yaitu yang sesuai dengan intelegensinya sendiri yang menonjol. Banyak guru mengajar selalu dengan cara yang sama, waktu yang sama, dan gaya yang sama. Padahal cara itu tidak sesuai dengan beberapa siswa yang berbeda intelegensinya. Maka, banyak siswa yang meskipun masuk sekolah, tetapi masih merasa tidak pernah dibantu belajar. Gardner mencoba membantu guru-guru tersebut untuk mengubah cara mengajar mereka, yaitu menggunakan multiple intelligences yang lebih bervariasi dan disesuaikan dengan intelegensi siswa.

Menurut multiple intelligences, setiap siswa mempunyai intelegensi yang berbeda dan siswa akan lebih mudah belajar dan dibantu belajar bila materi diajarkan dengan intelegensi mereka yang menonjol. Misalnya, bila siswa menonjol dalam intelegensi musik, ia akan mudah belajar mata pelajaran IPS, bila materinya diungkapkan dan dijelaskan dengan memasukkan unsur musik kedalamnya. Oleh karena intelegensi siswa di satu kelas bervariasi, maka guru perlu memasukkan dan mengolah materi yang akan diajarkan dengan model multiple intelligences sesuai dengan intelegensi siswa-siswa tersebut. Guruperlu mengajar dengan model yang bervariasi sehingga setiap siswa merasa perlu dibantu secara tepat. Maka, sangat baik sebelum mengajar guru mencoba mengenali intelegesi apa saja yang dimiliki siswanya.

Biasanya, guru karena mempunyai intelegensi tertentu yang menonjol, cenderung menggunakan pendekatan yang sesuai denganintelegensi tersebut terus-menerus. Guru yang mempunyai intelegensi matematis-logis tinggi akan lebih senang mengajar dengan menekankan pada pendekatan matematis-logis yakni secara sistematis, dengan skema, bagan, rumus, dan sebagainya. Guru yang menonjol dalam intelegensi linguistik akan senang mengajar dengan menggunakan model intelegensinya, seperti berceramah, bercerita panjang lebar, dengan puisi, membaca dan sebagainya. Guru yang intelegensi musiknya tinggi akan sering menggunakan lagu atau musik dalam mengajar. Guru tersebut jarang menggunakan pengajaran dengan intelegensi kinestetik-badani, interpersonal, ruang-visual, intrapersonal, lingkungan atau eksistensial. Akibatnya, siswa yang tidak berintelegensi sama dengan yang digunakan guru, tidak akan terbantu secara baik. Bahkan, bisa jadi siswa tersebut merasa tidak 
diajar apa pun, karena guru mengajar untuk siswa lain yang berintelegensi cocok dengan cara guru mengajar.

Menurut Gardner, secara umum guru dapat mengembangkan pembelajaran dengan menggunakan intelegensi lain yang tidak dikuasainya. Caranya dengan melatih metode tertentu yang sesuai dengan intelegensi yang mau dilatihkan. Misalnya, guru yang intelegensi musikalnya kurang baik dapat mengajar materi pelajaran dengan menggunakan lagu atau musik asal dia berlatih terus-menerus. Tentu kualitasnya tidak sebaik dengan guru yang intelegensi musikalnya baik, namun cukup untuk mengajar siswa. Dengan demikian, guru tidak boleh merasa tidak dapat berkembang lagi, tetapi harus lebih yakin bahwa selalu dapat mengembangkan cara mengajar mereka. Bila siswa dapat dibantu mengembangkan intelegensi mereka, intelegensi guru juga dapat dikembangkan.

Dalam penelitian dan percobaannya, Gardner menemukan banyak guru mengubah model mengajar mereka, banyak siswa merasa dibantu dalam menekuni pelajaran. Dalam banyak pengalaman, guru sendiri merasa dikembangkan karena ternyata mereka dapat berubah dan menggunakan banyak model pengajaran.

Secara umum implikasi multiple intelligences bagi guru adalah sebagai berikut: Guru perlu mengerti intelegensi siswa mereka, Guru perlu mengembangkan model mengajar dengan berbagai intelegensi, bukan hanya dengan intelegensi yang menonjol pada dirinya, Guru perlu mengajar sesuai dengan intelegensi siswa, bukan dengan intelegensi dirinya yang tidak cocok dengan intelegensi siswa, Dalam mengevaluasi kemajuan siswa, guru perlu menggunakanberbagai model yang cocok denagn multiple intelligences.

Dalam penelitian Gardner, kadang ada siswa merasa sudah puas bila belajar dengan membaca buku lalu mengerjakan soal yang tersedia. Bertahun-tahun dia hanya belajar dengan cara seperti itu. Memang siswa itu sudah mendapatkan sesuatu, namun sewaktu dikenalkan dengan berbagai cara belajar berdasarkan multiple intelligences, siswa akan terkejut karena ternyata ada beberapa cara belajar yang jauh lebih membantunya untuk berkembang. Disinilah pentingnya guru memperkenalkan berbagai model pembelajaran. Dengan demikian, semua kemampuan siswa dapat digunakan dan dikembangkan.

Proses pembelajaran pun harus bervariasi sehingga setiap siswa dapat menemukan bahwa mereka diperhatikan dan dibantu untuk belajar. Tidak ada model pembelajaran untuk segala pelajaran dan semua siswa. karena pendekatan bervariasi, jelas bahwa peralatan atau media pembelajaran pun bervariasi. Maka, sekolah perlu mempersiapkan dan menyediakan 
peralatan yang bermacam-macam seperti musik, video, alat tulis, ruang studi kelompok dan sebaginya. Tanpa peralatan yang sesuai, pembelajaran model multiple intelligences tidak akan berjalan dan guru cenderung akan kembali kepada pembelajaran klasik yaitu ceramah (Paul Suparno, 2013: 55-58).

\section{3) Implikasi pada pengaturan kelas}

Pendekatan pembelajaran yang bervariasi, karena intelegensi siswa dan intelegensi guru berbeda juga mempengaruhi pengaturan kelas. Kelas tidak hanya diatur dalam satu kedudukan yang tetap, berbaris dari depanke belakang. Kadang kelas harus diatur dengan kursi melingkar, atau harus dikosongkan untuk menari atau berkelompok kecil untuk diskusi dan sebagainya. Pengaturan kelas harus fleksibel, bervariasi sesuai dengan model multiple intelligences yang mau ditekankan.

Misalnya, untuk lebih mengembangkan intelegensi lingkungan, siswa diajak untuk membuat klasifikasi macam-macam benda atau keluar sekolah melihat hutan, taman, atau alam sekitar. Intelegensi kinestetikbadani membutuhkan ruang kelas yang lain dengan kelas ceramah atau penjelasan linguistik.

Belajar tidak boleh diibatasi di dalam gedung, kelas atau sekolah. Kadang demi pemahaman yang lebih mendalam dan mudah, belajar harus dilakukan di luar sekolah, bahkan di tempat yang jauh. Maka, model live in, model studi banding, model pengamatan di candi dan pegunungan, semuanya membutuhkan belajar di luar sekolah. Pembelajaran multiple intelligences memerlukan model-model pembelajaran tersebut (Paul Suparno, 2013: 60).

4) Implikasi pada evaluasi

Karena sistem pembelajaran dan pendekatan yang bervariasi, maka sistem evaluasi pun berbeda. Sistem evaluasi yang hanya dengan tes tertulis tidaklah cukup karena tidak mengungkapkan intelegensi yang mervariasi.

Dalam penelitiannya, Gardner menemukan ada seorang siswa yang sangat cerdas dalam menganalisa flora dan fauna dan sangat kreatif menjelaskan kepada siswa lain. Namun, siswa tersebut tidak berhasil, karena setiap kali ujian dengan cara menulis esai, dia selalu gagal. Gurunya tidak mengerti mengapa hal itu terjadi, maka siswa itu terpaksa tidak naik kelas. Ternyata siswa ini memang mempunyai intelegensi interpersonal dan intelegensi lingkungan 
tinggi, tetapi kurang menonjol dalam intelegensi linguistik. Siswa tersebut membutuhkan evaluasi yanglain, misalnya dengan ujian lisan, atau diminta mengekspresikan dengan cara lain.

Menurut Gardner, evaluasi yang tepat haruslah juga menggunakan multiple intelligences yang dipakai dalam pembelajaran. Evaluasi perlu menggunakan model yang memuat kemampuan intelegensi matematislogis, linguistik, kinestetik-badani, musik, ruang-visual, interpersonal, intrapersonal, lingkungan dan eksistensial. Setidaknya sesuai dengan pembelajaran, bila mengajarkan dengan cara musikal, perlu ada evaluasi yang bernada musikal, bila mengajarnya dengan kinestetik-badani, perlu evaluasi dengan kinestetik-badani pula.

Evaluasi yang dipandang cocok untuk model pembelajaran multiple intelligences adalah lewat performa siswa dalam situasi yang real, seperti pentas musik, melakukan kerja nyata, menyelesaikan proyek bersama, lewat praktikum, dan sebagainya. Lewat performa siswa dapat menunjukkan apa yang telah dipelajari dan diketahui dalam konteks yang sesuai dengan lingkungannya. Dengan demikian, evaluasinya sungguh autentik (Paul Suparno, 2013: $61)$.

Menurut Armstrong dalam bukunya yang berjudul Multiple Intelligences in The Classroom beberapa hal yang harus dilakukan guru agar evaluasinya autentik dan menyeluruh, diantaranya:

1) Guru perlu melihat bagaimana siswa menunjukkan prestasinya berkaitan dengan setiap intelegensi yang digunakan

2) Guru dapat mengumpulkan semua dokumen yang dihasilkan siswa selama proses pembelajaran (portofolio) sepertites formal,informal, tulisan, foto, pekerjaan, video yang dibuat, jurnal yang ditulis, hasil pekerjaan rumah, piagam, hasil interview, pengamatan selama pembelajaran, keaktifan di kelas, dan sebagainya.

3) Guru perlu mellihat bagaimana hasil kerja proyek bersama temantemannya

4) Tes tertulis pun harus bervariasi dan menyertakan multiple intelligences (Paul Suparno, 2013: 62).

\section{KESIMPULAN}

Teori multiple intelligence ditemukan dan dikembangkan oleh Howard Gardner, seorang ahli psikologi perkembangan dan profesor pendidikan dari Graduate School of Education, Harvard University, Amerika Serikat. Gardner memberikan definisi tentang kecerdasan, sebagai kecakapan untuk memecahkan masalah yang dihadapi, dalam kehidupannya, kecakapan untuk mengembangkan masalah baru untuk dipecahkan, dan 
kecakapan untuk membuat sesuatu atau melakukan sesuatu yang bermanfaat di dalam kehidupannya. Pada awal penelitiannya Gardner mengumpulkan banyak kemampuan manusia yang dapat dimasukkan dalam pengertian tentang intelegensi. Setelah semua kemampuan dianalisis dan diteliti, akhirnya dia menerima adanya tujuh intelegensi yang dimiliki manusia. Namun, pada bukunya Intelligence Reframed, ia menambahkan dua intelegensi baru, yaitu intelegensi lingkungan atau naturalis (naturalist intelligence) dan intelegensi eksistensial (existential intelligence).

Dalam pendidikan anak usia dini hendaknya memperhatikan kecerdasan yang dimiliki oleh anak. Karena kecerdasan anatara satu anak dengan yang lain berbeda. Orang tua maupun pendidik anak usia dini harus mengenali kecerdasan yang dimiliki anak agar dapat mengarahkan dan mengembangkan kecerdasan yang dimiliki anak secara maksimal. Teori Multiple Intelligences ketika diterapkan dalam pembelajaran merupakan suatu teori yang memperlakukan semua peserta didik dengan perlakuan yang sama dan istimewa. Siswa akan mudah memahamimateri yang disampaikan guru bila materi disampaikan dengan menggunakan intelegensi yang menonjol pada siswa. Maka guru perlu menggunakan strategi multiple intelligences dalam proses pembelajaran untuk mengembangkan seluruh kecerdasan siswa secara optimal. Pembelajaran multiple intelligences berorientasi pada pengembangan potensi anak bukan berorientasi pada idealisme guru atau orang tua. Anak berkembang agar mampu membuat penilaian atau keputusan sendiri secara tepat, bertanggung jawab, percaya diri dan mandiri tidak bergantung pada orang lain, kreatif, mampu berkolaborasi, serta dapat membedakan mana yang baik dan tidak baik. Dengan menggunakan pendekatan pembelajaran multiple intelligences dalam proses pembelajaran dapat tercipta pembelajaran yang sesuai dengan esensi dan substansi pendidikan dengan memperhatikan multiple intelligences peserta didik.

Ada sembilan intelegensi menurut Howard Gardner yaitu intelegensi liguistik, intelegensi matematislogis, intelegensi ruang-visual, intelegensi kinestetik-badani, intelegensi musikal, intelegensi interpersonal, intelegensi intrapersonal, intelegensi lingkungan, dan intelegensi eksistensial. Dengan memahami multiple intelligences para peserta didik, pendidik dapat menerapkannya dalam proses pembelajaran. Sehingga dalam proses kegiatan belajar mengajar di kelas tercipta pembelajaran yang sesuai dengan esensi dan substansi pendidikan dengan memperhatikan multiple intelligences peserta didik. 


\section{DAFTAR PUSTAKA}

Armstrong, Thomas. 2003. The Multiple Intelligences of Reading And Writing: Making The Words Come Alive. USA: ASCD

Baharudin dan Esa Nurwahyuni. 2007. Teori Belajar dan Pembelajaran. Yogyakarta: ArRuzz Media.

Chatib, Munif. 2012. Orangtuanya Manusia: Melejitkan Potensi dan Kecerdasan dengan Menghargai Fitrah Setiap Anak. Bandung: Kaifa.

Campbell, Linda and Bruce Campbell. 1999. Multiple Intelligences And Student Achievement : Success Stories From Six Schools. USA: ASCD

Dadang, Asep. 2007. Mencerdaskan Potensi IQ, EQ, dan SQ. Bandung : PT Globalindo Universal Multi Kreasi.

Dahar, Ratna Wilis. 2011. Teori-Teori Belajar dan Pembelajaran. Jakarta: Erlangga

Djaali. 2007. Psikologi Pendidikan. Jakarta : Bumi Aksara.

Efendi, Agus. 2005. Revolusi Kecerdasan Abad 21: Kritik MI, EI, SQ, AQ dan Succesful Intellegences atas IQ. Bandung: Alfabeta.

Gardner, Howard. 2013. Multiple Intelligences: Memaksimalkan Potensi dan Kecerdasan Individu dari Masa Kanak-kanak hingga Dewasa. Jakarta: Daras Books.

Julia, Jamine. 2007. Mengajar Berbasis Multiple Intelligences. Bandung : Nuansa.

Sanjaya, Wina. 2008. Kurikulum dan Pembelajaran:Teori Praktik Pengembangan Kurikulum Tingkat Satuan Pendidikan (KTSP). Jakarta: Kencana Prenada Media Group.

Slameto. 2010. Belajar dan Faktor-faktor yang Mempengaruhinya. Jakarta : PT Rineka Cipta.

Soefandi, Indra. 2009. Strategi Mengembangkan Potensi Kecerdasan Anak. Jakarta: Bee Media Indonesia.

Solihatin, Etin dan Raharjo. 2009. Cooperative Learning Analisis Model Pembelajaran IPS. Jakarta: Bumi Aksara.

Sukmadinata, Nana Sayodih. 2011. Landasan Psikologi: Proses dan Pendidikan.Bandung: PT Remaja Rosdakarya

Suparno, Paul. 2013. Teori Kecerdasan Ganda dan Aplikasinya di Sekolah: Cara Menerapkan Teori Multiple Intelligences Howard Gardner, Yogyakarta: Kanisius.

Syah, Muhibbin. 2000. Psikologi Belajar. Jakarta: Bumi Aksara. 
Homepage: www.syekhnurjati.ac.id/jurnal/index.php/awlady

E-mail: pgrasyekhnurjati@gmail.com

P-ISSN: 2541-4658

Uno, Hamzah B. 2010. Orientasi Baru dalam Psikologi Pembelajaran. Jakarta: Bumi Aksara.

Widayati, Sri dan Widjiati, Utami. 2008. Mengoptimalkan 9 Zona Kecerdasan Majemuk Anak. Jogjakarta: Luna Publisher 